Article

\title{
Planning for Community Based Tourism in a Remote Location
}

\section{Sharon Harwood}

Coffey Environments, Level 1 2-3 Greenhill Rd, Wayville, South Australia 5034, Australia; E-Mail: harwood@squirrel.com.au; Tel.: +61-872-213-500; Fax: +61-881-721-968.

Received: 26 May 2010; in revised form: 6 June 2010 / Accepted: 16 June 2010 /

Published: 1 July 2010

\begin{abstract}
Remote areas are difficult to access, tend to lack critical infrastructure, are highly susceptible to shocks in the marketplace, and are perceived by industry to possess limited development opportunities. Accordingly a community orientated and territorial approach to development planning in a remote area will be more successful than a top down industry based approach [1]. Given the limitations of being remote, the case study community examined in this research manages and sustains a bird watching tourism product within a global market place. This paper examines how a remotely located community in the Arfak Mountains of West Papua overcomes these difficulties and plans for community based tourism (CBT) in their locale.
\end{abstract}

Keywords: community based tourism; remote; planning; tourism; West Papua; bird watching

\section{Introduction}

The word planning may be used in different ways and as a society we accept the term planning to describe a variety of activities such as financial planning, transport planning, social planning and business planning. These planning activities share some common themes irrespective of the subject matter. These include [2]:

- Concerned with the future;

- About acquiring information;

- Anticipating or forecasting change under conditions that are often uncertain;

- The development of a strategic vision;

- The evaluation of different course of action;

- Facilitating political decision making; and

- Value laden and political. 
The term planning is used in this paper to refer to the publicly guided transformation of space [3]. Planning is a process of human forethought and the subsequent actions based upon that thought that are focused upon the future [4]. Planning is future orientated and simultaneously optimistic because it assumes the ability of the humans within the system to control the forces that impact upon the future [4].

Community based planning is a form of planning that focuses on the grass roots level of the community as the alternative to a top down approach [5]. There are many definitions of what constitutes a community. Geographers emphasise spatial aspects in their definitions, economists examine work and markets and sociologists emphasise social interactions and networks in their definitions of community [6]. The concept of community can also be referred to as a community of practice whereby the networks of people are geographically dispersed but are linked by a shared set of interests or experiences [7]. In general terms the various definitions of a community all use some combination of space, people and social interactions [6]. For the purposes of this research the term community will refer to people whom one identifies within a specific locale [8].

For postmodernists the notion of community represents a desire to regain what has been lost as a result of modernity $[8,9]$. In this sense community offers an alternative to modern society and the opportunity to gain something that was lost when people were transformed from an agrarian community structure to that of an industrialised society. It is perceived that social networks, a sense of belonging and self identity were lost in the industrial transformation of society [10]. Moreover, the notion of community assumes that the individual places the benefit of the collective over their own [9] in the belief that those within the collective reciprocate the action in their decision making. Unlike those in modern society who operate under the premise of self interest or individualism [8].

Criticisms of "community" abound in relation to social homogeneity, exclusion of minorities and that community represents a search for something that was never possessed in the first place $[8,9]$. However the notion of community is significant to planning in remote locations, as it provides a rich description of the relationship that a collection of relatively isolated people have with both the social and spatial attributes associated with their territory. The purpose of this paper is to examine how a remotely located community in the Arfak Mountains of West Papua plan for community based tourism (CBT). More specifically the investigation sought information on how land uses associated with bird watching tourism were assessed and in turn how the community defined an appropriate level of development.

\section{Community Based Tourism as Community Development, Community Engagement and as a Planning Process}

CBT centres on the involvement of the host community in the planning, construction, maintenance and management aspects of tourism development. This implies that the host community has involvement in, control over or ownership of the planning outcomes. The tourism literature describes CBT in two ways. One of which focuses on community development through tourism [11-14] the second on community engagement with the affected community in the planning of tourism as a land use [15-19] and the subsequent development of a tourism venture [20-23] to promote long term relationships between service providers and clients. 


\subsection{Community Based Tourism as Community Development}

The primary purpose of CBT as a community development outcome is to provide development opportunities that distribute benefits that otherwise do not exist across a community. These benefits include economic returns, while also empowering a community with the skills and resources to develop a sustainable tourism enterprise. This form of CBT focuses on removing constraints to participation in tourism and developing the human capital of the locale such as gender equality [13], creating local employment [14] entrepreneurial training and education for locals [24] and on devising and applying a comprehensive community development process to tourism planning [25]. The community development approach to CBT views tourism as an economic driver that enables each community member to have equal access to an improved quality of life. The premise behind tourism in this sense is that the industry will provide economic benefits that are not available from current economic development strategies. The process that the community undergoes in deciding the types of tourism that it will be involved in focuses on building capacity. The planning process enables the community to access information regarding tourism; make informed decision on issues related to tourism; influence the decision making process and to have the skills to participate in tourism enterprises.

CBT as a community development exercise is a long and complex process that has had lower than anticipated rates of success [14]. Furthermore, research on Thailand's oldest ecotourism company found that there are tradeoffs to be made in CBT ventures namely ([14], p. 613):

- Success and survival at the expense of spatial isolation and structural independences;

- Local employment and benefits at the expense of local initiation and control;

- Social status and mobility at the expense of social cohesion and harmony; and

- Incipient environmentalism at the expense of ecological sustainability.

Moreover, [26] cautions against communities considering tourism as a strategy for community development, as tourism may not provide a secure economic future due to insufficient demand, oversupply of tourism ventures and the impact of the global economy upon the ability of people to undertake tourism in times of recessions. [11] views tourism as being exploitative in a slightly different manner and maintains that CBT processes do not allow a community to be empowered; rather it serves to ensure the long term survival of a profitable tourism industry. In this sense [11] maintains that the community is not empowered to reject tourism as a development option, and as such they have no real influence or power over the economic strategies that are undertaken. [11] highlights concerns that are equally shared by [27], related to the role of power and politics in tourism planning and the influence that these have upon empowering a community in the decision making process. However, [27] maintains that transparent decision making and planning processes are the most effective way to ensure community empowerment. 


\subsection{Community Based Tourism as Community Engagement}

Engagement is the term used to describe a two way communication process between the community and the planning agency and/or the developer. The level of influence that the community has within the planning process can range along a spectrum of no involvement, to one of being empowered with the ability to make and control the outcome [28]. Planning should precede development [29], and the level of community engagement for each development is dependent upon a range of variables such as legislative requirements; nature of the development and associated impacts; and the commitment of the developers and regulators to empowering the community to make informed decisions [30].

Land use planning refers to the process of identifying the sequence of actions necessary to achieve a predetermined goal or objective for sustainable land use on a specified portion of land. These planning activities according to ([31], p. 31) share seven common steps:

- The setting of the vision, goals and objectives;

- The collection and analyses of relevant data and information;

- A public involvement process;

- The evaluation of alternative future scenarios;

- The selection and implementation of a course of action and associated policies;

- The establishment of a monitoring and evaluation process; and

- A feedback mechanism to ensure adaptive management as a response to changing circumstances and new information.

The planning process described above has an implicit level of community involvement in each step. However the extent to which members of the tourism affected community are actually involved depends upon the type of planning system that governs land use decision making. The notion of CBT however, explicitly states that the community has control over the planning system that governs land use decisions and planning is therefore dependent upon community involvement throughout each of the seven steps.

Tourism researchers generally agree that it is beneficial for the tourism project to have community involvement in the planning and development stages. Involving communities can:

- enhance local socio economic benefits [15];

- increase the limits of local tolerance through participation by locals in the tourism development process [20];

- assist communities to be more responsive to intensifying competition from the globalisation of trade, business and travel [18]; and

- help secure the commitment of local people, without which the sustainable development of tourism is extremely difficult if not impossible [21].

Interestingly, in the above justifications for public engagement in tourism planning and development, the community does not have the opportunity to feel empowered with the ability to reject tourism as an economic development strategy. The community may be involved, but not empowered. 


\subsection{Community Based Tourism as a Planning Procedure}

[25] combines the two approaches of community development and engagement to tourism planning. In the process set forward by [25], the community have the ability to reject tourism by being empowered with the overall control in the decision making process, in addition to being in control over the gathering and interpretation of knowledge with which these decisions are based upon. Essentially [25], believes that CBT is a combination of both community development and engagement.

According to [25] CBT should focus on the involvement of a community in the planning process to guide the intensity and location of tourism development. Once the community have made these decisions they will then be in a position to own, operate, manage and control tourism development within their community. [25] describes the planning process (Figure 1) to guide the community based tourism planning practice to achieve "community friendly and people centred" development ([25], p. 121). Moreover the procedure outlined by [25] is based on the premise that tourism will be sustainable when a community reaches a collective decision. This decision is reached through the identification of commonly held values and aspirations for development. The corresponding level of development will therefore be commensurate with the community circumstances.

Figure 1. Community Tourism Planning Process (adapted from [25]).

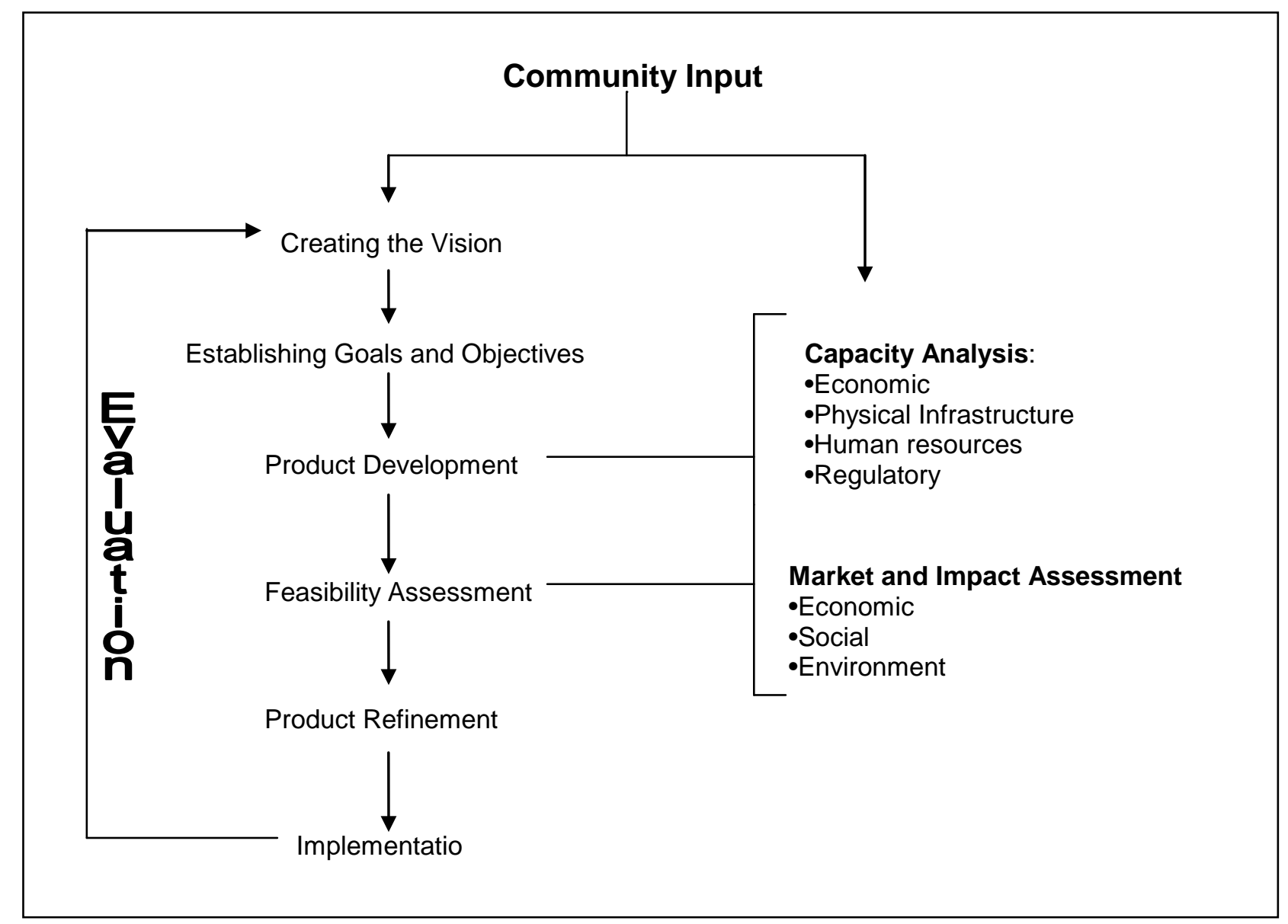


The process outlined in Figure 1 follows the classic approach to planning outlined by [31] and is comprised of ([25], p. 145):

- The creation of a vision to establish an overall framework for tourism development.

- The setting of goals and objectives to bring that vision about.

- The development of programs designed to accomplish the relevant objectives.

- An evaluation of the feasibility usually financial of the proposed project (if necessary and adaptation or refinement).

- The implementation and ongoing monitoring of the project established as a result of the planning and decision making process.

The distinguishing feature of the above process is that the role of data collection and analysis is removed from the analysts (experts) and given to the citizen and the local community to complete. The emphasis on economic rationality and the scientific approach in determining goals and aspirations is replaced with the collective wisdom of those involved in the decision making. The justification for this process is based upon [25] own account of communities that have lacked the necessary skills to create an overarching structure to control the direction of tourism. It should be noted that [25] is not anti-tourism, rather he stresses the importance of having a comprehensive community held vision of their desired future that is supported by a strategic plan. This vision and accompanying strategic plan describes the overall development direction. [25] further maintains that the plan formulation process should involve the local people in the day to day aspects including local groups to complete relevant research projects.

\section{Methods}

The focus of the research is to gain an understanding of the process that a remote community applies as they plan for bird watching tourism development in their locale. The research applies the single case study method to guide the research methods. The case study site examined in this research was chosen because it provides information on an extreme and yet simultaneously paradigmatic case [32]. The site is extreme in that it provides information on how a community in a remote area plans for development in the absence of infrastructure. While also paradigmatic in that the case study further develops the paradigm of planning for CBT as a practice in a remote location.

Three key informants were identified and interviewed for the purpose of the research. Each informant was specifically targeted as they played a role in decision making regarding land use within the village area. The informants were interviewed to determine how decisions were made regarding tourism development within the village locality. The key informants interviewed (and are subsequently coded) were the West Papua based tour operator (TO); the village based field guide and tourism co-ordinator (TG); and the head of the village responsible for all land use assessments and plot allocations (LO).

\section{Case Study Location}

The case study site is located in the remote Arfak Mountains of West Papua (Figure 2).

The community provides a range of services such as food, accommodation and guiding services to bird watching tourists. The community is referred to as Village \#3 to protect its identity and to 
distinguish it from the two other villages within the Arfak Mountains that had been used in times past for the purposes of bird watching tourism. Village \#3 is seasonally accessible by road from the nearest City (Cit \#1) and is comprised of 17 houses and one church. Farm lands surround the village and these areas are enclosed by montane forest and steep topography. The people of the community all speak the local language of Hatam, the younger generations speak Bahasa Indonesia and only one resident within the community (interview: TG) speaks limited English.

Figure 2. The Study Area.

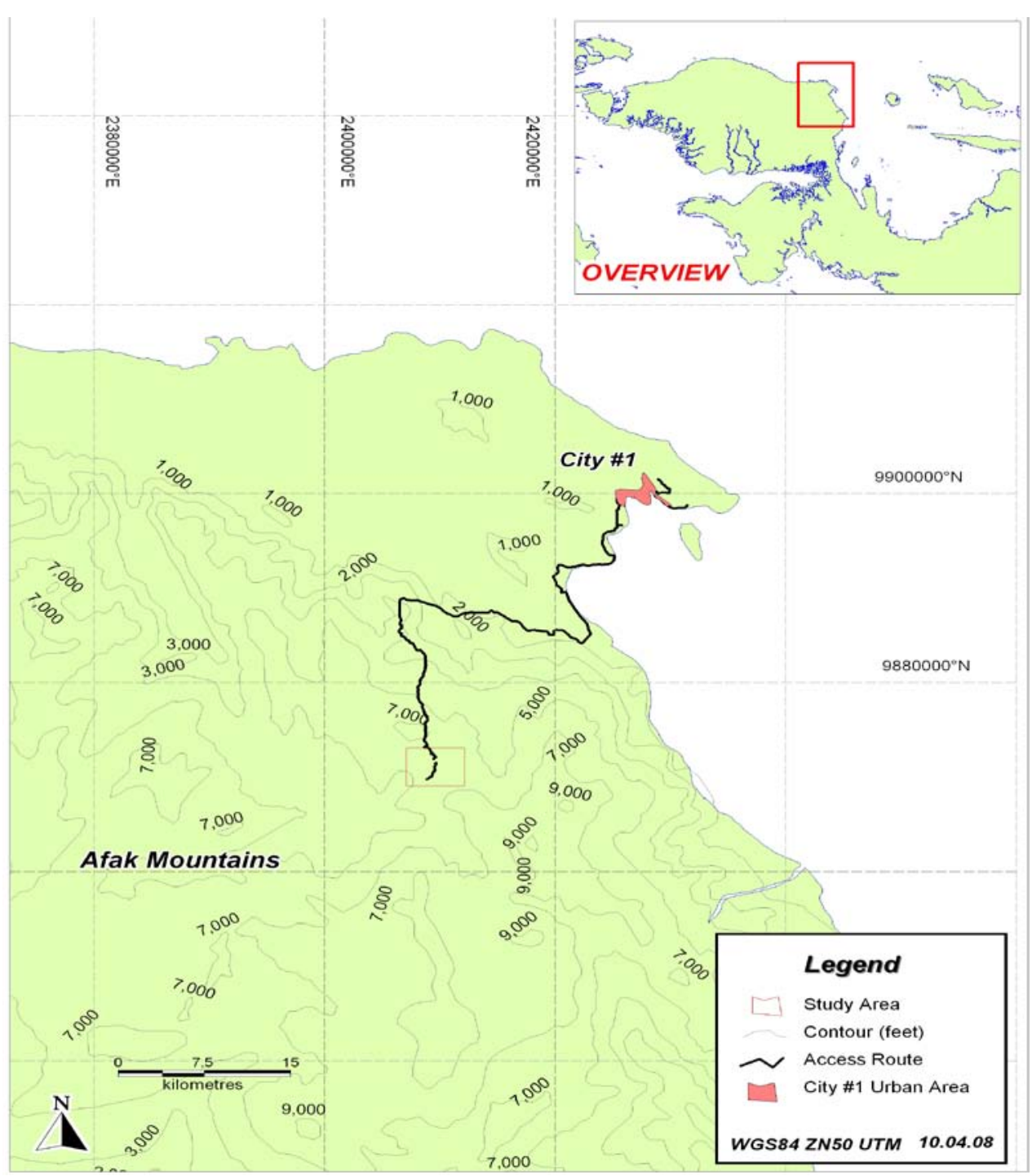

At the time of the data collection (May 2008) 80\% of the village community were involved in tourism and dependent upon tourism for $100 \%$ of their cash income. The remaining $20 \%$ of families are dependent upon agriculture of which they sell 50\% of their produce and consume the remainder (interview: TG). All families have a house in the main village area, a farming allocation to grow their own food, and were able to access the forest (for food such as mushrooms and possum) to supplement their diet and timber for firewood or construction.

The village has no public infrastructure such as electricity, water, sewerage or telecommunications. There are no schools within the village and children must walk $2 \mathrm{~km}$ to a neighbouring village to attend 
primary classes. All secondary education is provided in City \#1, and children must be sent away as the village is not within commuting distance. The national government does not provide for secondary school for the remote area communities and as such the family must pay for tuition and boarding fees.

The local economy is highly specialized with $80 \%$ in tourism and $20 \%$ in part time agriculture. Prior to tourism the main economic base of the village was subsistence agriculture. The residents continue to grow sweet potato, cabbage, passionfruit and tamarillo's for sale at the local mountain and city markets. However, despite its remoteness the village supplies a tourism product to bird watchers who come from all over the world (specifically from the USA, UK, Australia and Europe) to see the birds inhabiting the locale. The community does not possess telecommunication infrastructure, language skills used by the tourists or hold secure title to their land resource. The community does however own and control the tourism venture(s) that support the tourism product.

The Arfakans are Melanesians and as such have a strong affinity with the land and a marked sense of belonging to a place [33]. Customary land tenure depends on kin relationships and as such individuals do not have freehold title to any parcel of land and the rights to use the land are allocated by the "landowner". The landowner inherited the Village \#3 territory from his forebears, and allocates use rights to specified areas for his kin to live, farm and hunt. Notwithstanding this fact, the land is legally owned by the "state", which invariably means that should the state want access to the resources of Village \#3 such as its timber, they are legally able to take these without consulting or compensating the community.

Given the limitations imposed by being remote such as lacking critical infrastructure, possessing relatively few product choices, and being highly susceptible to shocks in the marketplace, the tourism venture provides a range of benefits to the majority of the community. The following section examines how the decisions within this community are made about what to supply, and describes the practice of CBT applied by the community.

\section{Community Based Bird Watching Tourism}

\subsection{How the Community Became Involved in Tourism}

The local residents have no personal experience of the notion of tourism or bird watching tourism as they do not compartmentalise their life in terms of work and leisure as other cultures do [34]. To the local Arfakans the forest is a resource to enable subsistence and as a bank of resources for future generations.

The initiator of tourism in the mountains (TO) was an Indonesian field guide accompanying a science expedition 1990. The TO arranged to bring tourists to Village \#1, and the TG would subsequently host the visitors in his home and provide guide services throughout the mountain region. The business arrangement between the TO and the TG is such that they operate as two separate entities. The TO sources the tourists and then takes them to the village where the TG provides guide services and accommodation and organizes for food and porters. The initial site for tourism (referred to as Village \#1) was abandoned due to conflict between the cost for porter services charged by the residents and the operators perception that the rate did not equate to quality service provision. The TO and TG decided not to use any of the people from the Village to assist in supplying services 
and continued to bring bird watchers to Village \#1. The people of the Village retaliated to this exclusion by informing the Indonesian Army that the bird watchers were trespassing on their land. The Indonesian Army came to the Village and held an International tour leader in custody, leaving the TO and the TG to negotiate and secure the release of the tour leader.

After the resolution of this conflict, the TO and TG came to the conclusion that if tourism in the Arfaks was to continue then the TG would have to leave Village \#1 and find another place to base himself out of. The TG moved to Village \#2 and continued to accept tourists accompanying the TO. The residents of Village \#2 provided porter services. On one particular occasion the TO brought a tour group for an extended tour through the Mountain region and was accompanied by the TG and the porters from Village \#2. It was the habit of the TO to employ porters from Villages where the tour utilised their community owned forested land for bird watching. On this particular trip, unbeknown to TO and TG a married female porter from Village \#2 allegedly had sexual relations with a male porter from one of the other Villages in the region. When the tour concluded the TG returned to Village \#2 with the resident porters. News of the affair become known within Village \#2 and conflict between residents and the TG ensued. The residents believed that the affair was inappropriate and as it occurred on a tourism related trip it became the responsibility of the TG to accept the consequences.

Death threats were subsequently made to the TO and TG. The TG decided to leave Village \#2 and in 2004 the TG sought permission from the land owner of Village \#3 to reside in his Village and to conduct tourism in the adjacent forested lands. The Landowner (LO) granted the TG permission to live in the TG's brothers' house. It should be noted at this point that the TG and the LO identify with each other as kin. In 2004 the TO initiated a system whereby every time the TG brought a group to visit the Village and forested lands they made a land owner payment referred to as "landowner fees". In addition, the landowners' youngest son was provided with a scholarship by the TO to attend high school in City \#1.

It appears that the TO and TG understood the precarious nature of tourism and the impact that this could have upon both the social and economic values within a community. Thus since 2004 the TO makes regular donations to the Village church as the church is the central place of the Village (spatially and spiritually) that provides the opportunity for interaction with other members the community and to share common spiritual beliefs. These donations are used to provide resources for Sunday school and contribute to the maintenance of the church vegetable garden which is used to supply food at church gatherings.

The previous experience of the TO and TG appear to have influenced the way that they interacted with the community in Village \#3. In addition the TG devised a rotating roster system so that all members of the Village could have equal access to the alternate cash income stream provided by tourism. Village residents are able to supply vegetables, firewood and porter services. A training system has also been established by the TG in the areas of bird watching guide services and cooking. Three young men are being trained in bird identification by the TG and several young women are being trained by the cook (wife of TG) in kitchen duties such as cooking and food preparation. All employees are residents of the Village. The tours utilise the land associated with the Village territory and no outsiders are employed by the TG or the TO so as to avoid any repercussions. 


\subsection{Decision Making}

Figure 3 illustrates the relationship between the entities within the community based tourism system. The tourist purchases a product in the form of a tour from either an international or the West Papua (TO) based tour operator. Either way the TO is the contact used by both the community and the international operator to book the tour and describe the birds sought at each location and organises all internal Indonesian travel. The TO does not book itineraries in advance rather they respond to demand for tours.

Figure 3. Relationship within the Tourism System at Village \#3.

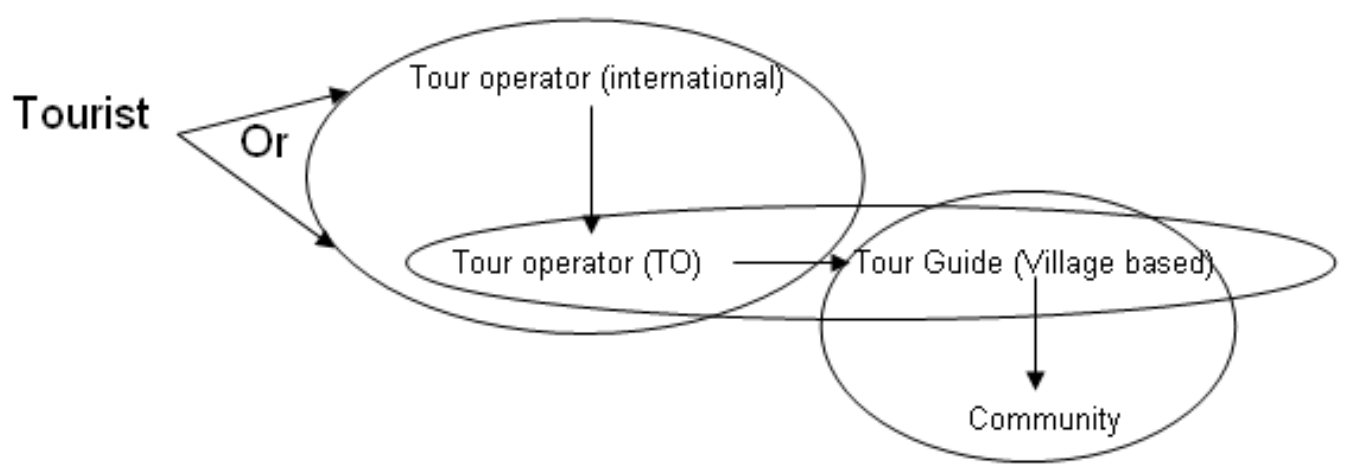

The TG provides all field guiding services, liaison with community providers and accommodation at the Guest House. The TG does not liaise directly with the tourists as he is responsible for service provision within his Village. The TG speaks little English (other than the English names of birds) and does not have access to information and communication technology to communicate with the rest of the world.

The communication process that has adapted in the absence of telecommunication infrastructure and knowledge of a common language has meant that decisions regarding tourism are centred on those individuals able to exchange information. Tourists therefore must utilise the communication channels that are able to make these connections possible on their behalf. This invariably means that the TG is dependent upon his interaction with the TO to connect with the wider world of bird watchers, similarly the internationally based operators are dependent upon the TO to organise tours on behalf of their clients.

\subsection{Land Use Assessment System}

There is no available literature that outlines how decisions are made within Arfak Mountain communities with respect to land use. The Indonesian Adat system does not apply to the people of this locality as the residents do not identify with the Indonesian system. The people of the Arfak Mountains broadly identify themselves as Hatam yet identify specifically with a Village locale within the Hatam speaking Arfak Mountains. The Hatam speakers are the indigenous people of the Arfak Mountains who identify themselves as Papuans not as Indonesians. Papuans are indigenous to the island of New Guinea and are known as Melanesians. Accordingly one of the few things that characterise nearly all Melanesians is their relationship with their land [33], to which they all possess rights. 
According to the rules of the traditional customary land tenure systems, Melanesians cannot permanently alienate land to strangers i.e. people not related by kinship ties [33]. Land tenure depends upon kin relationships and while an individual does not hold "freehold title" to a particular parcel of land, they do possess use rights to defined plots. Among the Hatam, the land owner (the original settler or descendent thereof) defines the land plots to be used by his kin. The land owner has sole discretion over who is given an allocation and where the allocation is to be located.

The Village \#3 LO is self sufficient and does not produce surplus food from his farm. His only form of cash income is from tourism in the form of land owner fees and if there is an emergency and he needs money he asks his sister to sell his vegetables in town, but this is very rare (LO).

The dominant land uses granted by the LO have been a plot for farming in the mountain sides and a plot within the Village for a house. As all the land belongs to him he has sole discretion to determine the location, type, scale and intensity of development. Once granted these use rights belong to the kin member and can be passed down to the following three generations. After three generations the next must move to another Village (interview TO). Areas can be traded, however all changes in the use of the land must be approved by the landowner.

Figure 4. Description of Predominant Hatam Tenure Types.

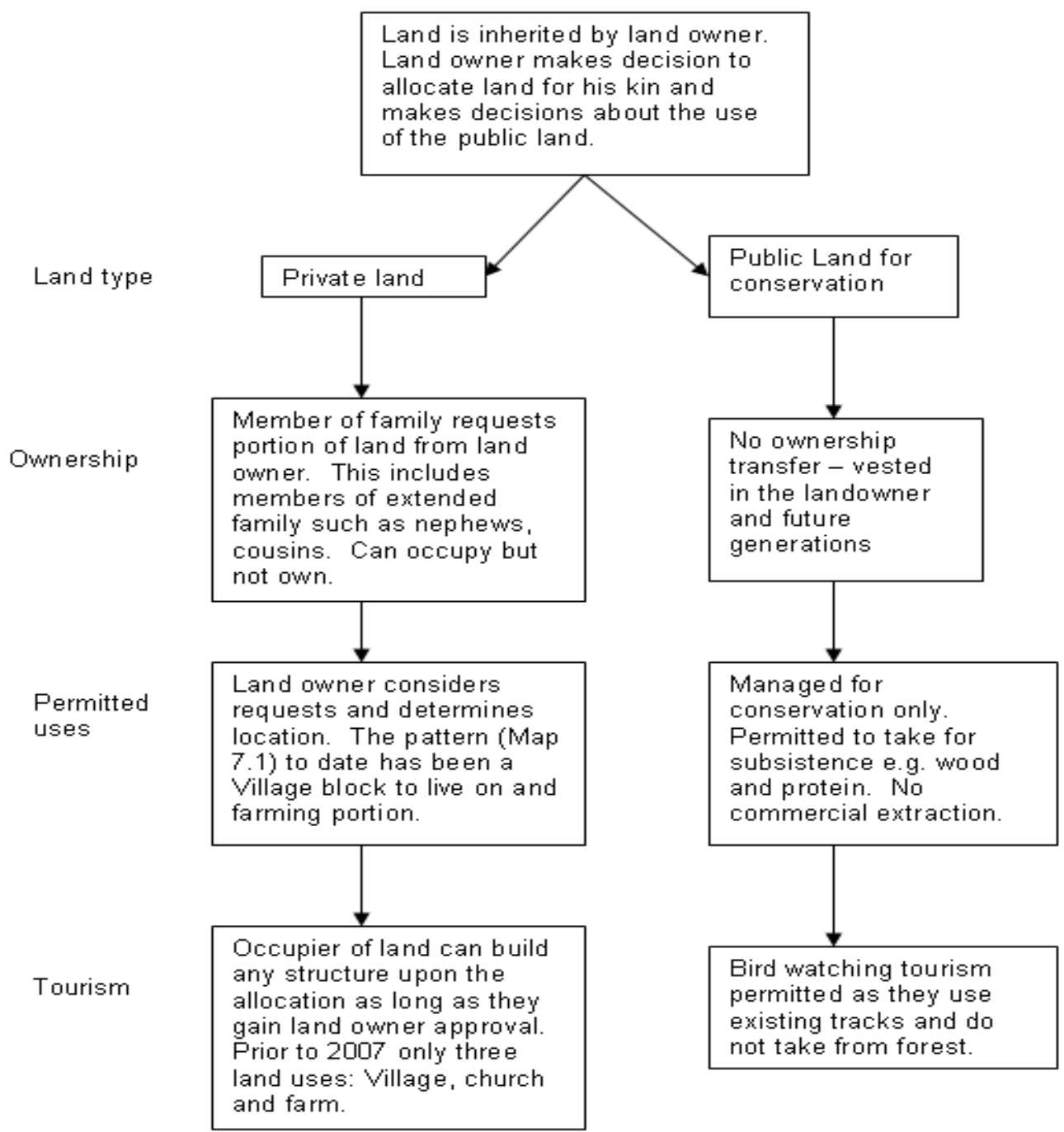


There are no direct opportunities provided to the community to have input into decisions relating to changes in land use. There are four types of land uses within the Village those being religion (church), farming, residential and tourism and two types of tenures within the Village locale (Figure 4). The land tenure system is broadly described upon the basis of two tenure types those being private land that can be used for development and public land that is managed for conservation purposes.

Private land may be developed for housing, tourism and farming. The other type relates to the forested mountain lands (public estate/commons) that are not to be developed for commercial gain, but are able to be used by all of the Villagers (with permission from the land owner) for subsistence. This would include forest products for housing, hunting for food such as possum and gathering of mushrooms and other food sources.

The customary land tenure system and the formal (state) property system are two separate processes governing land ownership and title over the same area. Accordingly the state is the legal owner of the land and all rights to its use are legally vested in the state.

\section{Discussion and Conclusions: A New Conceptualization for CBT}

The governance strategies applied within Village \#3 sees the role of the LO as an assessor of land use who also determines the appropriate location (based on kinship relations) for development. The ability of the business to sustain itself both within the community and in the market place is the responsibility of the developer (TG and TO), irrespective of the benefits that the community derive from the use. The developers were unsuccessful in building the necessary relationship between the business operation and the community in Villages \#1 \& \#2 and subsequently unable to sustain the business in these locales. On the third attempt the developers realised how integral the community is in relation to the ability of the business to remain in its location and to sustaining its place in the market.

The community development perspective of CBT [11] maintains that tourism is owned, operated and controlled by the local community. In the instance of this case study the rules that govern the property rights and ownership of the land determine the ownership structure of enterprises. Therefore only people who are related to the LO are able to use the land within the Village locale, while the LO retains overall ownership of the land. All use rights and development is assessed and approved by the LO and the community accept and function within these local governance structures.

Tourism in Village \#3 is community based in the sense that a person can participate in the roster to access a cash income. It is not community based in the sense that the arrangement was made to put the needs of the community above those of the individual. Each person in Village \#3 behaves to satisfy their individual needs and for as long as these individual needs are met, then the enterprise will continue to operate within the Village.

CBT in Village \#3 shares some of the characteristics of the community development and community engagement perspectives. However, in Village \#3 tourism was deliberately based on ensuring the satisfaction of individual aspirations. The magnitude of income generated by tourism in Village \#3 is far greater than any member had experienced from the traditional part time agricultural economic base. The greatest issue for the TG was ensuring that each household who wanted to be involved was provided equal opportunity. The TG found that when each person has their aspirations met there is no outward conflict between its members and tourism. 
The CBT planning process outlined by [25] was based upon the premise that tourism is sustainable when it reaches a collective decision and that the decision is reached through the identification of commonly held views and aspirations for development. However, the community of Village \#3 while not able to have direct input in to the land use assessment phase is able to influence the business operation within the community and locale. The attempts to establish tourism in Village \# 1 and \# 2 were unsuccessful as the operation of the development conflicted with the aspirations of the more influential members of the Village community. The development was approved, but this is seen as separate to the operation of the business.

These results suggest that establishing opportunities for a remotely located community to benefit from tourism underpins the success of the tourism product within a community. [35] maintains that resident attitudes towards tourism will be positive where they are the recipients of benefits derived from the enterprise. The LO did not have to intervene at the time of assessment by conditioning the development in Village \#3 to provide benefits to the community. Rather the developers had learnt from previous attempts that the business was contingent upon community support for its survival. The process that has evolved within this Village further suggests that planning for tourism development is comprised of two separate yet inextricably connected processes. On the one hand a land use planning process that identifies the suitable and the appropriate location and type of development. On the other hand a planning process for a tourism product includes consideration of the scale and intensity of development commensurate with community support and involvement.

The results from this investigation indicate that there are two key types of pre development conditions that are fundamental to community based development in this remote area. The first of which is access to a formal property system. While the LO of Village \#3 administers the customary land tenure system, the legal ownership of the land has been vested in the regional government. If the regional government decides to sell land use rights such as timber or mineral extraction it is under no obligation to consider customary land tenure arrangements or compensate businesses operating within the customary system. The second essential pre development condition is the presence of physical infrastructure such as telecommunications and electricity. While the case study community examined in this research demonstrates that development is not impossible in the absence of infrastructure, the community requires growth to fund critical infrastructure. Moreover, this community is unable to create growth as they are unable to legally secure the development rights to their customary title to fund increased productivity.

In sum, planning is predicated upon controlling the forces that impact upon the future and in the absence of local ownership of tenure, the community does not possess the ability to control the future or create community based development. Therefore future research efforts should systematically examine how property systems can be enhanced to remove structures that may cause remote communities to be developmentally disenfranchised.

\section{Acknowledgements}

I gratefully acknowledge Charles Darwin University and CSC for providing the postgraduate scholarship to allow me to complete my PhD thesis, the supervision provided by Dean Carson and 
Richard Noske, the contributions that the residents of Village \#3 made to this research and my professional development and thank Andrew Harwood for giving his time to complete my maps.

\section{References}

1. Markey, S.; Halseth, G.; Manson, D. The struggle to compete: From comparative to competitive advantage in Northern British Columbia. Int. Plan. Stud. 2006, 11, 19-39.

2. Dredge, D.; Jenkins, J. Tourism Planning and Policy; John Wiley and Sons: San Francisco, CA, USA, 2007.

3. Yiftachel, O. Essay: Reengaging Planning Theory? Towards South Eastern Perspectives. Plan. Theory 2006, 5, 211-222.

4. Chadwick, G. A Systems View of Planning: Towards a Theory of the Urban and Regional Planning Process; Pergamon Press: Oxford, UK, 1971.

5. De Beer, F.; Marais, M. Rural communities, the natural environment and development-Some challenges, some successes. Community Dev. J. 2005, 40, 50-61.

6. Kumar, C. Revisiting "community" in community-based natural resource management. Community Dev. J. 2005, 40, 275-285.

7. Community Engagement and Development Booklet; Centre for Social Responsibility in Mining, Department of Industry, Tourism and Resources: Brisbane, Australia, 2006.

8. Young, I. City Life and Difference. In Readings in Planning Theory 1990; Campbell, S., Fainstein, S., Eds.; Blackwell Publishing: Edinburgh, UK, 2003; pp. 336-355.

9. Delanty, G. Community; Routledge: London, UK, 2003.

10. Lalli, M. Urban Related Identity: Theory, Measurement, and Empirical Findings. J. Environ. Psychol. 1992, 12, 285-303.

11. Blackstock, K. A critical look at community based tourism. Community Dev. J. 2005, 40, 39-49.

12. Jones, S. Community Based Ecotourism: The Significance of Social Capital. Ann. Tourism. Res. 2005, 22, 303-324.

13. Scheyvens, R. Promoting women's empowerment through involvement in ecotourism: Experiences from the third world. J. Sustain. Tourism 2000, 8, 232-218.

14. Kontongeorgopoulos, N. Community Based Ecotourism in Phuket and Ao Phangnga Thailand: Partial Victories and Bittersweet Remedies. J. Sustain. Tourism 2005, 13, 4-23.

15. Mitchell, R.; Eagles, P. An Integrative Approach to Tourism: Lessons from the Andes of Peru. J. Sustain. Tourism 2001, 9, 4-28.

16. Reed, M. Power Relations and Community Based Tourism Planning. Ann. Tourism. Res. 1997, 24, 566-591.

17. Prentice, R. Community driven tourism planning and residents preferences. Tourism Manage. 1993, 14, 218-227.

18. Jamal, T.; Getz, D. Collaboration Theory and Community Tourism Planning. Ann. Tourism. Res. 1995, 22, 186-204.

19. Macbeth, J.; Carson, D.; Northcote, J. Social Capital, Tourism and Regional Development: SPCC as a Basis for Innovation and Sustainability. Curr. Issue. Tourism 2004. 7, 502-521. 
20. Tosun, C. Limits to community participation in the tourism development process in developing countries. Tourism Manage. 2000, 21, 613-633.

21. Sautter, E.; Leisen, B. Managing Stakeholders: A Tourism Planning Model. Ann. Tourism. Res. 1999, 26, 312-328.

22. Clifton, J.; Benson, A. Planning for Sustainable Ecotourism: The Case for Research Ecotourism in Developing Country Destinations. J. Sustain. Tourism 2006, 14, 238-254.

23. Binns, T.; Nel, E. Tourism as a local development strategy in South Africa. Geogr. J. 2002, 168, 235-247.

24. Timothy, D. Building Community Awareness of Tourism in a Developing Country Destination. Tour. Recreat. Res. 2000, 25, 111-116.

25. Reid, D. Tourism, Globalisation and Development: Responsible Tourism Planning; Pluto Press: London, UK, 2003.

26. Ife, J. Community Development: Community Based Alternatives in an Age of Globalization, 2nd ed.; Pearson Education: Cranbury, NJ, USA, 2002.

27. Hall, C.M. Politics and Place: An Analysis of Power in Tourism Communities in Tourism in Destination Communities; Singh, S., Timothy, D., Dowling, R., Eds.; CABI Publishing: Wallingford, CT, USA, 2003; pp. 99-113.

28. Public Participation Spectrum; International Association for Public Participation: Wallingford, CT, USA, 2007; Available online: http://www.iap2.org/associations/4748/files/Spectrum.pdf (accessed on 3 December 2007).

29. Costa, C. An Emerging Tourism Planning Paradigm? A Comparative Analysis between Town and Tourism Planning. Int. J. Tourism Res. 2001, 3, 425-441.

30. Development Assessment Forum-A Leading Practice Model for Development Assessment in Australia; Department of Transport and Regional Services: Canberra, Australia, 2005.

31. Low Choy, D.; Worral, R.H.; Gleeson, J.; Mckay, P.; Robinson, J. Environmental Planning Project: Volume 1-Management Framework, Tools and Co-operative Methods; Technical Report; CRC for Coastal Zone Estuary and Waterway Management: Sydney, Australia, 2002; Volume 4, p. 234.

32. Flyvberg, B. Five Misunderstanding about Case Study Research. Qual. Inq. 2006, 12, 219-245.

33. Sillitoe, P. Social Change in Melanesia: Development and History; Cambridge University Press: Cambridge, UK, 2000.

34. Iso Ahola, S. The Social Psychology of Leisure and Recreation; WCB Company Publishers: Houston, TX, USA, 1980.

35. Harrill, R. Residents' attitudes toward tourism development: A literature review with implications for tourism planning. J. Plan. Lit. 2004, 18, 251-266.

(C) 2010 by the authors; licensee MDPI, Basel, Switzerland. This article is an Open Access article distributed under the terms and conditions of the Creative Commons Attribution license (http://creativecommons.org/licenses/by/3.0/). 